\title{
Alcohol and Breast Cancer Incidence and Outcome: A Minireview of Literature
}

\author{
Rizwan Qamar', Mashhood A. Syed ${ }^{2}$, Jonatahn Yin Amtul R. Carmichael2* \\ ${ }^{1}$ Department of Histopathology, Russells Hall Hospital, Dudley, UK \\ ${ }^{2}$ Department of General Surgery, Russells Hall Hospital, Dudley, UK \\ Email: Amtul.Carmichael@dgh.nhs.uk
}

Received 13 May 2014; revised 23 June 2014; accepted 3 August 2014

Copyright (C) 2014 by authors and OALib.

This work is licensed under the Creative Commons Attribution International License (CC BY). http://creativecommons.org/licenses/by/4.0/

(c) (i) Open Access

\begin{abstract}
There is strong epidemiological evidence, based on 15 prospective studies, 10 meta-analyses, and 5 systematic reviews involving more than 2.2 million patients, that alcohol consumption is a contributing factor for the development of breast cancer. The evidence regarding the effect of alcohol consumption on breast cancer outcome needs to be gathered in order to draw firm conclusions regarding alcohol consumption after breast cancer diagnosis. In this article, we aim to review the current literature regarding recurrence and all-cause and BC cause mortality and identify postulated. We would make suggestions for future research.
\end{abstract}

\section{Keywords}

Breast Cancer, Alcohol Consumption, Recurrence, Mortality

Subject Areas: Oncology, Surgery \& Surgical Specialties, Women's Health

\section{Introduction}

Robust epidemiological and scientific evidence has recognised the carcinogenic effects of alcohol on the development of cancer of the oral cavity, the pharynx, the larynx, as well as the squamous cell carcinoma of the oesophagus and the liver [1]-[3]. The evidence that alcohol plays a causal role in the development of breast cancer (BC) has consolidated recently [4] [5]. The exact cause of breast cancer is unknown, and the development of breast cancer is attributable to the life time exposure of Oestrogen. The incidence of breast cancer is higher in postmenopausal obese women, those from deprived backgrounds, and is lower in premenopausal obese women. The exact mechanism by which alcohol exerts its carcinogenic effect on BC is not fully understood.

\section{Alcohol Intake}

According to the NHS guidelines in the UK, women should not regularly exceed more than 2 - 3 units per day

*Corresponding author.

How to cite this paper: Qamar, R., Syed, M.A. and Carmichael, J.Y.A.R. (2014) Alcohol and Breast Cancer Incidence and Outcome: A Minireview of Literature. Open Access Library Journal, 1: e753. http://dx.doi.org/10.4236/oalib.1100753 
(equivalent to 16 - $24 \mathrm{~g}$ ethanol/day) [5] [6], which is equivalent to 1 pint of strong lager (3 units) or 1 large glass of wine (3 units). According to the NHS guidelines the categories of alcohol consumption and risk are as following. Lower Risk-No more than 2 - 3 units (One unit equals $10 \mathrm{ml}$ or $8 \mathrm{~g}$ of pure alcohol) per day on a regular basis, Increasing Risk-More than 2 - 3 units per day on a regular basis, Higher Risk-More than 35 units per week on a regular basis [56].

\section{Alcohol Intake and BC Incidence}

A clear dose-response relationship between alcohol consumption and the development of BC was shown in a pooled analysis of $>300,000$ women recruited in 6 prospective studies from North America and Europe [6]. Each $10 \mathrm{~g}$ increment of alcohol consumed increased the relative risk of developing BC by 9\% (95\% CI, 1.04 - 1.13) [6]. The dose response relationship was suggested by a linear increase in the risk of developing BC with an increasing alcohol intake of up to $60 \mathrm{~g}$ per day. It is estimated that consuming two or more drinks per day (equivalent to $\geq 30 \mathrm{~g}$ ), increased the risk of developing BC by $40 \%$ [6]-[9]. In a recent large meta-analysis Hamajima et al. (2002) examined data from 53 studies including more than 58,000 women with invasive BC and more than 95,000 controls. The relative risk of developing BC was increased by $32 \%(19 \%-45 \%, P<0.00001)$ and $46 \%$ (33\% - 61\%, $P<0.00001$ ) respectively, for intakes of $35-44 \mathrm{~g} /$ day and $\geq 45 \mathrm{~g} /$ day compared to non-drinkers [10]. Similarly for each additional $10 \mathrm{~g}$ /day of alcohol intake the relative risk was increased by $7 \%$ (5.5\% - 8.7\%, $P<0.00001$ ) [10]. More recently "The Million Women Study", a large prospective cohort study following approximately 1.3 million women from the NHSBSP (National Health Service Breast Screening Programme) has reaffirmed the association between alcohol consumption and developing breast cancer. It was shown that an increase in alcohol consumption of $10 \mathrm{~g} /$ day resulted in a $12 \%$ increased risk of BC (95\% CI $=1.09-1.14, P_{\text {trend }}<$ 0.001) [2]. A dose response relationship was also suggested by Chen et al. (2011) in a prospective observational study of >100,000 women; every $10 \mathrm{~g}$ increment of alcohol consumed increased relative risk of developing BC by 7\% [11]. This association was further consolidated by The World Cancer Research Fund (WCRF) Reportin 2010; the review of evidence found that 31 out of 57 of its investigated studies showed a significantly increased risk of BC related to increased alcohol consumption [12]. In their second expert report; a meta-analysis of cohort studies showed that $10 \mathrm{~g}$ consumption of ethanol led to a $10 \%$ increased risk for all-age breast cancer, a $9 \%$ increased risk for premenopausal BC and a $8 \%$ increased risk for postmenopausal breast cancer; thus the (WCRF) report classed the evidence for alcohol as a cause for BC as convincing [13].

Even consumption of small amounts of alcohol has been shown to increase the risk of developing breast cancer. A review of the evidence in 2012 concluded that having 1 alcoholic drink/day ( 1.5 units) increased the risk by 4\% [14]. This finding was further supported by a meta-analysis by Bagnardi et al. (2013) which looked specifically at the effects of light alcohol consumption (up to 1 drink/day); 222 articles were evaluated which included $~ 92,000$ light drinkers and 60,000 non-drinkers with cancer. Light drinking was significantly associated with the risk of developing BC $(\mathrm{RR}=1.05$; 95\% CI 1.02 - 1.08) [15].

However, an association between alcohol consumption and BC is not undisputed. Zhang and Holman (2011) reported that low to moderate alcohol intake ( $<10 \mathrm{~g} /$ day) was not associated with increased risk of BC in pre- or postmenopausal women (a case-control study of 1009 breast cancer and 1009 age-matched controls in China) [16]. In fact they showed an inverse relationship with development of $\mathrm{BC}$ for $<10 \mathrm{~g}$ of Ethanol consumed daily (For $>0-<5$ g/day OR 0.56 (CI $0.45-0.69, P<0.001$ ), and for $>5-<10$ g/day OR 0.58 (CI $0.35-0.98, P=$ 0.04). However, their data also showed a significant association between consuming $\geq 30 \mathrm{~g}$ ethanol/day and development of BC (OR 2.33 (CI 1.26 - 4.31, P $<0.01$ ). This study supports the hypothesis that increased alcohol intake can increase the risk of developing BC.

\section{The Proposed Mechanisms Linking Alcohol with BC Development}

The exact mechanism by which alcohol may promote carcinogenesis is not fully understood. In a recent review article Brooks and Zakhari (2012) consolidated much of the known and postulated mechanisms by which alcohol is thought to contribute to the development of breast cancer. They arrived at two distinct mechanisms by which alcohol may act, firstly as a breast tumour promoter and secondly as a weak cumulative breast carcinogen [36].

It is postulated that alcohol may cause DNA damage, elevated levels of steroid hormones, and enhanced gland susceptibility [17]. Alcohol interferes with folate absorption, transport, and metabolism causing or exacerbating 
a pre-existing folate deficiency [31]. Folate deficiency has been implicated in carcinogenesis through aberrations in DNA synthesis, and through the depletion of labile methyl groups needed for methylation reactions [32].

Acetaldehyde, the primary metabolite of alcohol in the human body has also been implicated in carcinogenesis. The International Agency for Research into Cancer (IARC) classifies acetaldehyde associated with alcohol drinking as a Group 1 Carcinogen [3]. Experimental evidence in animals has shown the conversion of ethanol to acetaldehyde in mammary tissue to have a significant effect on the progression of tumour development [33].

Experimental evidence also suggests that alcohol may enhance the metastatic potential of BC cells over expressing ErbB2 or HER2. Amplification of HER2 is found in $20 \%$ to $30 \%$ of patients with breast cancer [34]. Xu et al. (2010) investigated the effects of ethanol on attachment of HER2 + BC cells to human plasma fibronectin; an important constituent of the extra cellular matrix, and adhesion to it constitutes a key initial step in cancer cell invasion and metastasis. They found that exposure to ethanol drastically enhanced adhesion of HER2 $+\mathrm{BC}$ cells to fibronectin [35].

A possible explanation for the association between alcohol and BC includes hormone dependent mechanisms mediated by sex hormone receptors [18] [21]. Many studies have been undertaken to investigate an association between alcohol intake and BC risk dependent on oestrogen receptor (ER) and progesterone receptor (PR) status (Table 1) [19] [25]. The findings have been inconsistent, probably due to incomplete information on receptor status [19] [20] [24]-[27]. A meta-analysis of seven case-control and three cohort studies assessed the association between alcohol intake and the risk of ER-/PR- defined BC found statistically significant increased risks for all $\mathrm{ER}+(12 \%)$, all ER- (7\%), ER+PR+ (11\%) and ER+PR- (15\%), but not ER-PR- with an increased consumption of alcohol by $10 \mathrm{~g}$ per day [28]. The expression and proliferation of ERs in cultured human BC cells is increased by alcohol and therefore could possibly be associated with the development of positive, but not negative ER BC cells [25] [29] [30]. Furthermore, it is thought that the use of aromatase inhibitors and other anti-oestrogen therapy could possibly counteract the effects of alcohol on the endogenous oestrogen supply [17] [25] [30].

Table 1. Association between alcohol intake and breast cancer risk depending on ER and PR status.

\begin{tabular}{|c|c|c|c|}
\hline Author & $\begin{array}{l}\text { Number } \\
\text { of cases }\end{array}$ & $\begin{array}{l}\text { Hormonal status } \\
\text { of patients used }\end{array}$ & Results \\
\hline $\begin{array}{l}\text { R. Suzuki } \\
\text { et al., } 2005 \\
\quad[20]\end{array}$ & 1188 & Postmenopausal & $\begin{array}{l}\text { Alcohol consumption was associated with an increased risk for the development of } \\
\text { ER-positive }(+) \text { tumours, irrespective of PR status. } \\
\text { Highest intake ( } \geq 10 \text { g of alcohol per day) vs. non-drinkers, multivariable relative risk (RR): } \\
1.35 \text { ( } 95 \% \mathrm{CI}: 1.02 \text { to } 1.80) ; P \text { trend }<0.049 \text { for ER+PR+ tumours; and RR: } 2.36 \text { ( } 95 \% \mathrm{CI} \text { : } \\
1.56 \text { to } 3.56) \text {; } P \text { trend }<0.001 \text { for ER+PR- tumours. } \\
\text { No association was observed between alcohol intake and the risk of developing ER-tumours. }\end{array}$ \\
\hline $\begin{array}{l}\text { L. U. } \\
\text { Rosenberg } \\
\text { et al., } 2006 \\
\quad[22]\end{array}$ & 3345 & Postmenopausal & $\begin{array}{l}\text { Alcohol intake of }>10 \mathrm{~g} / \mathrm{d} \text { was associated with a seemingly higher risk of ER-PR-tumours } \\
\text { odds ratio (OR): } 1.6 \text { (95\% CI: } 0.9 \text { to } 2.7) \text { than for ER+PR+ tumours, OR: } 1.0 \text { ( } 95 \% \mathrm{CI} \text { : } \\
0.6 \text { to } 1.6 \text { ) compared with no recent alcohol intake. }\end{array}$ \\
\hline $\begin{array}{l}\text { M. Cotterchio } \\
\text { et al., } 2003 \\
\quad[23]\end{array}$ & 3276 & $\begin{array}{l}\text { Pre- and } \\
\text { Postmenopausal }\end{array}$ & $\begin{array}{l}\text { Compared with non-drinkers, heavy consumption of alcohol ( }>3.5 \text { alcoholic beverages/week) } \\
\text { was associated with a non-statistically significant increased risk of ER-PR- breast cancer } \\
\text { but was not associated with ER-PR- breast cancer. } \\
\text { Consuming moderate amounts of alcohol }(1-2.5 \text { drinks/week) was associated with an } \\
\text { increased risk of ER-PR- tumours (not statistically significant) but was not associated with } \\
\text { ER-PR- tumours. The heterogeneity between these MVORs was statistically significant } \\
(P=0.03) .\end{array}$ \\
\hline $\begin{array}{l}\text { S. M. Enger } \\
\text { et al., } 1999 \\
\quad[27]\end{array}$ & 1184 & $\begin{array}{l}\text { Pre- and } \\
\text { Postmenopausal }\end{array}$ & $\begin{array}{l}\text { Alcohol use not associated with premenopausal risk of breast cancer, regardless of } \\
\text { hormone-receptor status. } \\
\text { In postmenopausal women, those who consumed, on average, }>27 \mathrm{~g} \text { of alcohol/d } \\
\text { experienced an OR: } 1.76 \text { ( } 95 \% \text { CI: } 1.14 \text { to } 2.71 \text { ) for ER-positive/PR-positive breast } \\
\text { cancer relative to women who reported no alcohol consumption. }\end{array}$ \\
\hline $\begin{array}{l}\text { M. B. Terry } \\
\text { et al., } 2006 \\
\quad[24]\end{array}$ & 1508 & $\begin{array}{c}\text { Pre- and } \\
\text { Postmenopausal }\end{array}$ & $\begin{array}{l}\text { Alcohol consumption of approximately one drink per day was associated with ER-positive } \\
\text { tumours among women with a BMI }<25 \text {, but not among women with a BMI of } 25 \text { or more. }\end{array}$ \\
\hline $\begin{array}{l}\text { S. M. Zhang } \\
\text { et al., } 2007 \\
\quad[25]\end{array}$ & 1484 & $\begin{array}{l}\text { Pre- and } \\
\text { Postmenopausal }\end{array}$ & $\begin{array}{l}\text { An increased risk was limited to ER and PR positive tumours; the multivariable relative risks } \\
\text { for an increment of } 10 \mathrm{~g} / \text { day of alcohol were } 1.11 \text { (95\% CI: } 1.03,1.20) \text { for ER+PR+ tumours } \\
\text { ( } 804 \text { cases), } 1.00 \text { ( } 95 \% \text { CI: } 0.81,1.24) \text { for ER+PR- tumours ( } 125 \text { cases), and } 0.99 \text { (95\% CI: } \\
0.82,1.20 \text { ) for ER-PR- tumours ( } 167 \text { cases). }\end{array}$ \\
\hline
\end{tabular}




\section{Alcohol and BC Outcome}

A possible role of alcohol consumption in BC recurrence and mortality has received little research attention. There have been multiple studies investigating alcohol and mortality as the primary endpoint [29] [30] [37]-[48], but few which have specifically considered alcohol in relation to BC recurrence [30] [40] [44] [49]-[53].

We shall first consider studies investigating alcohol and overall mortality in women with BC. There are no specific studies addressing the overall moratlity in breast cancer survivors in terms of alcohol consumption. However, studies by Reding [29] and Wu [54] address this question to some extent. This remains an area for future research.

\subsection{Breast Cancer, Alcohol and Overall Mortality}

Six out of 8 studies published between 1991 and 2008 showed no association of alcohol intake and mortality. A further 6 recent prospective studies published between 2008 and 2013 were identified, which reported decreased overall mortality associated with increased alcohol intake [42]-[47].

Barnett et al. (2008) showed a $2 \%$ reduction $(95 \%$ CI, $1 \%$ to $3 \% P=0.0045)$ in mortality per unit of alcohol consumed per week, however, after adjusting for Type 1 errors, the association was no longer significant $\left(P_{\text {adj }}=\right.$ $0.144)$ [42].

Reding et al. (2008) found that all levels of alcohol consumption prior to a diagnosis of BC were associated with reduced risk of death [ $>0$ to $<3$ drinks per week: HR $=0.7$ (95\% CI: $0.6-0.95$ ); 3 to $<7$ drinks per week: $\mathrm{RR}=0.6$ (95\% CI: 0.4 - 0.8); $\geq 7$ drinks per week: RR = 0.7 (95\% CI: 0.5 - 0.9)] [29].

Flatt et al. (2010), Beasley et al. (2011), Harris et al. (2012), and Newcomb et al. (2013) all showed a significant reduction in all-cause or other-cause (excluding breast related) mortality associated with alcohol consumption [44]-[47]. Newcomb et al. (2013) demonstrated a 15\% relative reduction in breast cancer-specific mortality in those who were modest drinkers (3 to 6 drinks/week) prior to diagnosis [47].

Wu et al. (2013) in the California BC Survivorship Consortium (CBCSC) pooled data from 6 California based studies including more than 12,000 women with invasive BC. Although not commented on, their results showed that alcohol consumption was associated with a reduction in overall mortality. Alcohol related mortality was not a primary endpoint of the study; it was one of the multitude of variables for which data had been collected in the individual studies. It was also noted that individual studies varied in their method of collection, some documenting alcohol use as a continuous variable, and others as a categorical variable which arguably limits the usefulness of the data in making significant conclusions. It was also not clear if there had been adjustment for Type 1 error [54].

It is well recognised that moderate alcohol intake is associated with lower overall coronary heart disease related mortality in women. The apparent reduced mortality among drinkers in these studies could be due to a reduction in cardiovascular mortality [48].

\subsection{Breast Cancer, Alcohol and BC Recurrence}

To the authors' knowledge, there have been only eight studies that have examined the influence of alcohol on BC recurrence (Table 2). Four of the studies found no association between alcohol and recurrence.

Holm et al. (1993) followed 240 patients who had had surgically treated stage I-II non-metastatic BC for 4 years; this study found no association between alcohol intake and BC recurrence [49].

Saxe et al. (1999) followed 149 patients with non-metastatic BC for at least five years and reported that consuming two alcoholic drinks per week was not associated with the risk of BC recurrence [40].

Flatt et al. (2010) studied alcohol consumption in 3088 women treated for invasive BC with a median follow up of 7 years. Their results concluded that light alcohol intake (10 - $299 \mathrm{~g} / \mathrm{month})$, regardless of body weight, did not increase the risk of $\mathrm{BC}$ recurrence or all-cause mortality in the cohort of middle-aged women previously diagnosed with BC. In fact the study showed an association between alcohol consumption and reduction in allcause mortality. The authors of the study proposed several confounding factors to explain this. These included amongst others; women with more serious disease were more likely to be minimal drinkers; and women who were more highly educated were less likely to be minimal drinkers [44].

Vrieling et al. (2012) assessed the association of pre-diagnostic alcohol consumption with survival and recurrence in a prospective cohort study in Germany, including 2522 postmenopausal BC patients aged 50 - 74 years 
Table 2. A summary of the studies on alcohol consumption and breast cancer outcome measured as recurrence and all cause mortality.

\begin{tabular}{|c|c|c|c|c|c|}
\hline Author & $\begin{array}{l}\text { No of cases, } \\
\text { tumour stages }\end{array}$ & $\begin{array}{c}\text { Mean } \\
\text { follow-up }\end{array}$ & End points & $\begin{array}{c}\text { Menopausal } \\
\text { status and/or age }\end{array}$ & Results \\
\hline $\begin{array}{c}\text { M. L. Kwan } \\
\text { et al., } 2010 \\
{[30]}\end{array}$ & $\begin{array}{l}\text { 1897, Stages } \\
\text { I to IIIa }\end{array}$ & 7 & $\begin{array}{l}\text { Recurrence } \\
\text { rate, all-cause } \\
\text { mortality }\end{array}$ & $\begin{array}{c}\text { Pre-/ } \\
\text { Post- } \\
\text { menopausal }\end{array}$ & $\begin{array}{l}\text { Alcohol consumption (> } 6 \text { g/d) vs. non drinkers. } \\
\text { Recurrence rate: drinkers ( } \mathrm{n}=478,74 \text { events) vs. non-drinkers } \\
\text { (n=939, } 126 \text { events), HR } 1.35 \text { (95\% CI: } 1.00 \text { to } 1.83) \text {. } \\
\text { All cause mortality: drinkers ( } \mathrm{n}=478,64 \text { deaths) vs. non-drinkers } \\
\text { (n=939, } 135 \text { deaths) HR } 1.19 \text { (95\% CI: } 0.87 \text { to } 1.62) \text {. }\end{array}$ \\
\hline $\begin{array}{c}\text { J. R. Herbert } \\
\text { et al., } 1998 \\
{[51]}\end{array}$ & $\begin{array}{l}\text { 472, Stages } \\
\text { I to IIIa }\end{array}$ & 9 & $\begin{array}{l}\text { Recurrence } \\
\text { rate and } \\
\text { Breast cancer } \\
\text { mortality }\end{array}$ & $\begin{array}{l}20 \text { to } 80 \\
\text { years }\end{array}$ & $\begin{array}{l}\text { After accounting for disease stage and age, reported baseline } \\
\text { consumption of beer ( } 12 \text { oz drinks/d) (HR 1.58; } 95 \% \text { CI: } \\
1.15 \text { to } 2.17 \text { ) increased the risk of recurrence. Breast cancer } \\
\text { deaths (HR 2.33; } 95 \% \text { CI: } 1.35 \text { to } 4.00) \text {. }\end{array}$ \\
\hline $\begin{array}{c}\text { M. Holm } \\
\text { et al., } 2013 \\
{[52]}\end{array}$ & $\begin{array}{c}1052, \\
\text { Stage not } \\
\text { specified }\end{array}$ & $\begin{array}{l}\text { Median } \\
\text { follow-up } \\
6 \text { years }\end{array}$ & $\begin{array}{l}\text { Recurrence } \\
\text { rate and } \\
\text { Breast cancer } \\
\text { specific } \\
\text { mortality }\end{array}$ & 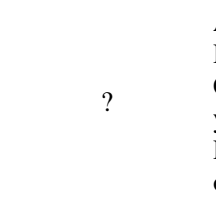 & $\begin{array}{l}\text { Alcohol intake }>2 \text { units/day vs. } \leq 1 \text { unit/day Recurrence rate: } \\
\text { HR } 1.65 \text { (95\% CI: } 1.02 \text { to } 2.67) \text {. } \\
\text { Cumulated alcohol intake }>40 \text { drinking years vs. } 0<\text { drinking } \\
\text { years } \leq 10 \text {; recurrence rate: HR } 2.02 \text { (95\% CI: } 1.06 \text { to } 3.85) \text {. } \\
\text { Results for breast cancer specific mortality were suggestive } \\
\text { of a higher risk but not statistically significant. }\end{array}$ \\
\hline $\begin{array}{c}\text { G. A. Saxe } \\
\text { et al., } 1999 \\
{[40]}\end{array}$ & $\begin{array}{l}\text { 149, Primary } \\
\text { breast cancer }\end{array}$ & 5 & $\begin{array}{l}\text { Recurrence } \\
\text { rate, all-cause } \\
\text { mortality }\end{array}$ & $\begin{array}{l}\text { Pre-/Post- } \\
\text { menopausal }\end{array}$ & $\begin{array}{l}\text { Alcohol Consumption (per } 2 \text { drinks/week). } \\
\text { Recurrence rate }(\mathrm{n}=149,28 \text { events) HR } 0.71 \\
\text { (95\% CI: } 0.32 \text { to } 1.57) \text {. } \\
\text { All cause mortality: }(\mathrm{n}=149,26 \text { deaths) HR } 1.09 \\
\text { (95\% CI } 0.81 \text { to } 1.46) \text {. }\end{array}$ \\
\hline $\begin{array}{c}\text { S. W. Flatt } \\
\text { et al., } 2010 \\
{[44]}\end{array}$ & $\begin{array}{l}\text { 3088, Stages } \\
\text { I to IIIa }\end{array}$ & 7.3 & $\begin{array}{l}\text { Recurrence } \\
\text { rate, all-cause } \\
\text { mortality }\end{array}$ & $\begin{array}{l}\text { Pre-/Post- } \\
\text { menopausal }\end{array}$ & $\begin{array}{l}\text { Moderate alcohol consumption (>300 mg/month) vs. } \\
\text { alcohol <10 g/month. } \\
\text { Recurrence rate: drinkers ( } \mathrm{n}=634,100 \text { events) vs. non-drinkers } \\
\text { (n=1133, } 213 \text { events), HR } 0.91 \text { ( } 95 \% \text { CI: } 0.71 \text { to } 1.18) \text {. } \\
\text { All-cause mortality: drinkers ( } \mathrm{n}-634,52 \text { deaths) vs. non drinkers } \\
\text { (n=1133, } 139 \text { deaths), HR } 0.69 \text { (95\% CI: } 0.49 \text { to } 0.97) \text {. }\end{array}$ \\
\hline $\begin{array}{l}\text { A. Vrieling } \\
\text { et al., } 2012 \\
{[50]}\end{array}$ & $\begin{array}{l}\text { 2522, Stages } \\
\text { I to IIIa }\end{array}$ & 6 & $\begin{array}{l}\text { Recurrence } \\
\text { rate, all-cause } \\
\text { mortality }\end{array}$ & $\begin{array}{c}\text { Post- } \\
\text { menopausal, } \\
50 \text { to } 74 \text { years }\end{array}$ & $\begin{array}{l}\text { Alcohol consumption } \geq 12 \text { g/d vs. }<0.5 \text { g/d. } \\
\text { Recurrence rate: } \mathrm{HR}=1.08 \text { (95\% CI: } 0.73 \text { to } 1.58) . \\
\text { All-cause mortality: } \mathrm{HR} 1.28 \text { (95\% CI: } 0.90 \text { to } 1.81) \text {. }\end{array}$ \\
\hline
\end{tabular}

[50]. Authors concluded that alcohol consumption was non-linearly associated with increased BC-specific mortality ( $\geq 12$ g vs. $<0.5 \mathrm{~g} /$ day: $(\mathrm{HR})=1.74$, CI: $1.13,2.67$ ) but found that alcohol consumption was not associated with overall mortality or BC recurrence.

Herbert et al. (1998) reported that the risk of BC recurrence was increased with the consumption of a beer [51]. In a study of 472 women with early stage BC between 1982 and 1984, it was also found that after accounting for disease stage and age, baseline consumption of beer (drinks/day) $(\mathrm{RR}=1.58$; 95\% CI: 1.15 to 2.17) increased the risk of recurrence. The consumption of a daily beer was associated with a 1.4-fold increased risk of recurrence and a 1.6-fold increased risk of $\mathrm{BC}$ death. This study showed that $\mathrm{BC}$ recurrence and mortality were related to the consumption of beer among premenopausal but not postmenopausal women. It was noted that wine and liquor were not associated with increased risk of BC recurrence.

Kwan et al. (2010) investigated 1897 women with early stage BC (stage I with tumours $\geq 1 \mathrm{~cm}$, stage II or stage IIIA) diagnosed between 1997 and 2000 [30]. Kwan and colleagues reported that by drinking approximately one half of an alcoholic drink ( $\geq 6 \mathrm{~g} /$ day) after BC diagnosis, the risk of BC was increased. For recurrence, the RR was 1.35 (95\% CI: 1.00 to 1.83), and for breast cancer-specific mortality, the RR was 1.51 (95\% CI: 1.05 to 2.38). Their results suggest that consuming three to four standard drinks or more per week is associated with 1.3-fold increased BC recurrence and 1.5-fold increased risk of BC death especially in postmenopausal and overweight/obese women. Given that recurrence can be a difficult end point to achieve with precision for observational studies not performed in clinical settings; this study has the benefit of excellent follow up of BC recurrence. According to the authors, the overweight and obese women in this study were less likely to consume 
alcohol (4.03 median g/day) compared with normal weight women ( $6.50 \mathrm{~g} /$ day). Yet alcohol was still associated with a detrimental effect among heavier women.

Holm et al. (2013) investigated the association between pre-diagnostic alcohol consumption and BC recurrence and breast cancer-specific mortality in 1052 women diagnosed with early BC in a prospective cohort of 29 875 women [52]. They found a significant association between pre-diagnostic alcohol consumption and BC recurrence with a median follow-up of six years after date of diagnosis, both when using baseline measures of alcohol intake (HR, $1.65 ; 95 \%$ CI: 1.02 to $2.67 ;>2$ units/day vs. $\leq 1$ unit/day) and cumulative alcohol intake (HR, 2.02; 95\% CI: 1.06 to 3.85; $>40$ drinking years vs. $0<$ drinking years $\leq 10$ ). Results for BC specific mortality were also suggestive of a higher risk, but were not statistically significant.

Most recently, Kwan et al. (2013) investigated the effect of post-diagnosis alcohol consumption on BC recurrence and mortality. They examined data from 3 prospective cohort studies in the After BC Pooling Project (ABCPP) involving >9000 women diagnosed with non-metastatic breast cancer. After a mean follow up of 10.3 years 1646 recurrences and 1543 deaths had occurred. The overall intake of alcohol was not associated with BC recurrence or mortality. However the risk of recurrence varied significantly by menopausal status. Postmenopausal women who regularly consumed alcohol ( $\geq 6.0 \mathrm{~g} /$ day) had an increased risk of recurrence (HR, 1.19; $95 \%$ CI, 1.01 - 1.40) [53].

The above review of literature revealed a heterogenous association between BC outcome, of recurrence or mortality, and alcohol intake. This may be a reflection of variations in study design and experimental protocols of these independently carried out studies. The studies conducted by Kwan et al. (2010, 2013), Herbert et al. (1998), and Holm et al. (2013), showed a positive correlation between alcohol intake and BC recurrence [30] [51]-[53]. Conversely the studies conducted by Holm et al. (1993), Saxe et al. (1999), and Flatt et al. (2010) did not find any association between alcohol intake and BC recurrence [40] [44] [49]. These differences may be explained by the variation in sample size and the duration of follow up. The studies conducted by Holm et al (1993) and Saxe et al. (1999) may lack sufficient power due to their small sample size. Furthermore the former is based on data collected over 20 years ago; making these less relevant to current clinical practice. Other factors which may explain the variation in findings include; data on alcohol consumption was collected retrospectively, survival analyses were not always controlled for grade and stage of cancer, and lack of data on tumour characteristics such as Lymphovascular invasion, lymph node status, prevalence of triple negative and HER II positivity amongst these cohorts [2] [13].

In summary, two of the eight studies detailed above (Holm et al. (1993) and Saxe et al. (1999)), can arguably be excluded from the review due to small sample size and historical data. Furthermore Flatt et al. (2010) identified a number of significant confounding factors in their study, which brings into question the validity of their results, and lastly Vrieling et al. (2012), although not finding any association between alcohol and BC recurrence, did however find a significantly increased risk of BC specific mortality. Thus, given the above, it can be argued that the current weight of evidence is in favour of a positive association between alcohol consumption and $\mathrm{BC}$ recurrence.

It is recognised that determining an individual's alcohol status is more difficult than broadly categorizing each patient as a "drinker" or "non-drinker", or indeed as set alcohol statuses. Questionnaires based on alcohol consumption will always be subject to potential confounding variation. Whilst studies are dependent on questionnaires that require patients to be forthcoming with their own alcohol intake, they will be liable to error due to the social undesirability of excessive alcohol intake, and also being medically inadvisable [55]. Drinking statuses may indeed change; due to variance, whilst one must also consider the impact that a diagnosis can make on drinking habits. Many of the more recent studies delineate pre- and post-diagnostic alcohol consumption.

\section{Future Research}

Our literature review has highlighted the gap in the knowledge and evidence regarding the impact of alcohol consumption on BC outcome. Further research should be aimed at collecting data for alcohol consumption before and after the diagnosis of BC to capture the true impact of alcohol on BC outcome.

Future projects could see research into the potential use of biological markers, for example Ki67; a nuclear marker of cell proliferation. Additionally, other studies could look into the effect of genes such as CCNB1, MK167 and MYBL2; which potentially, could play a role in determining BC recurrence. 


\section{Conclusion}

Alcohol consumption increases the risk and can impact on the outcome of BC. Studies consistently demonstrated a dose-response relationship with significant increase in relative risk per $10 \mathrm{~g}$ increment in ethanol consumption [2] [6] [10] [11] [13]. Furthermore even light drinking (up to 1 drink/day) was shown to significantly affect BC risk [14] [15]. The link between alcohol consumption and BC recurrence remains inconclusive. Further research is required, which may be aided by the investigation into the role of biological markers and gene recognition.

\section{Conflict of Interest Statement}

There are no conflicts of interest to be declared. No financial support was requested or received in the production of this article.

\section{References}

[1] Boyle, P. and Boffetta, P. (2009) Alcohol Consumption and Breast Cancer Risk. Breast Cancer Research, 11, S3. http://dx.doi.org/10.1186/bcr2422

[2] Allen, N.E., Beral, V., Casabonne, D., et al. (2009) Moderate Alcohol Intake and Cancer Incidence in Women. Journal of the National Institute of Cancer, 101, 296-305. http://dx.doi.org/10.1093/jnci/djn514

[3] International Agency for Research on Cancer (2012) Personal Habits and Indoor Combustions. IARC Monographs, Volume 100E, International Agency for Research on Cancer, France, 377-503.

[4] Kushi, L.H., Byers, T., Doyle, C., et al. (2006) American Cancer Society Guidelines on Nutrition and Physical Activity for Cancer Prevention: Reducing the Risk of Cancer with Healthy Food Choices and Physical Activity. CA: A Cancer Journal for Clinicians, 56, 254-281. http://dx.doi.org/10.3322/canjclin.56.5.254

[5] Bandera, E.V. and August, D.A. (2009) Alcohol Consumption and Breast Cancer Survival. Journal of Clinical Oncology, 27, 1727-1733. http://dx.doi.org/10.1200/JCO.2009.21.3371

[6] Smith-Warner, S.A., Spiegelman, D., Yaun, S.S., et al. (1998) Alcohol and Breast Cancer in Women: A Pooled Analysis of Cohort Studies. Journal of the American Medical Association, 279, 535-540. http://dx.doi.org/10.1001/jama.279.7.535

[7] Singletary, K.W. and Gapstur, S.M. (2001) Alcohol and Breast Cancer: Review of Epidemiologic and Experimental Evidence and Potential Mechanisms. Journal of the American Medical Association, 286, 2143-2151. http://dx.doi.org/10.1001/jama.286.17.2143

[8] Ellison, R.C., Zhang, Y., Mclennan, C.E., et al. (2001) Exploring the Relation of Alcohol Consumption to Risk of Breast Cancer. American Journal of Epidemiology, 154, 740-747. http://dx.doi.org/10.1093/aje/154.8.740

[9] Chen, W.Y., Colditz, G.A., Rosner, B., et al. (2002) Use of Postmenopausal Hormones, Alcohol and Risk for Invasive Breast Cancer. Annals of Internal Medicine, 137, 798-804. http://dx.doi.org/10.7326/0003-4819-137-10-200211190-00008

[10] Hamajima, N., Hirose, K., Tajima, K., Rohan, T., Calle, E.E., Heath Jr., C.W., et al. (2002) Collaborative Group on Hormonal Factors in Breast Cancer. Alcohol, Tobacco and Breast Cancer-Collaborative Reanalysis of Individual Data from 53 Epidemiological Studies, Including 58,515 Women with Breast Cancer and 95,067 Women without the Disease. British Journal of Cancer, 87, 1234-1245. http://dx.doi.org/10.1038/sj.bjc.6600596

[11] Chen, W.Y., Rosner, B., Hankinson, S.E., Colditz, G.A. and Willett, W.C. (2011) Moderate Alcohol Consumption during Adult Life, Drinking Patterns, and Breast Cancer Risk. Journal of the American Medical Association, 306, 1884-1890. http://dx.doi.org/10.1001/jama.2011.1590

[12] Agnoli, C., Berrino, F., Canevari, S., Casazza, G., Colombo, C., Fusconi, E., et al. (2005) The Associations between Food, Nutrition and Physical Activity and the Risk of Breast Cancer and Underlying Mechanisms: In Support of the Revision of the World Cancer Research Fund International's Report on Diet, Nutrition, Physical Activity and Cancer [Internet]. World Cancer Research Fund International, London. [Updated June 2006] http://www.dietandcancerreport.org/cancer resource center/downloads/SLR/Breast SLR.pdf

[13] World Cancer Research Fund, American Institute for Cancer Research (2010) Continuous Update Project Report: Food, Nutrition, Physical Activity, and the Prevention of Breast Cancer. London.

[14] Seitz, H., Pelucchi, C., Bagnardi, V. and La Vecchia, C. (2012) Epidemiology and Pathophysiology of Alcohol and Breast Cancer: Update 2012. Alcohol and Alcoholism, 47, 204-212.

[15] Bagnardi, V., Rota, M., Botteri, E., Tramacere, I., Islami, F., Fedirko, V., et al. (2013) Light Alcohol Drinking and Cancer: A Meta-Analysis. Annals of Oncology, 24, 301-308. http://dx.doi.org/10.1093/annonc/mds337 
[16] Zhang, M. and Holman, C.D.J. (2011) Low to Moderate Alcohol Intake and Breast Cancer Risk in Chinese Women. British Journal of Cancer, 105, 1089-1095. http://dx.doi.org/10.1038/bjc.2011.302

[17] Althuis, M.D., Fergenbaum, J.H., Garcia-Closas, M., Brinton, L.A., Madigan, M.P. and Sherman, M.E. (2004) Etiology of Hormone Receptor-Defined Breast Cancer: A Systematic Review of the Literature. Cancer, Epidemiology Biomarkers and Prevention, 13, 1558-1568.

[18] Dumitrescu, R.G. and Shields, P.G. (2005) The Etiology of Alcohol-Induced Breast Cancer. Alcohol, 35, $213-225$. http://dx.doi.org/10.1016/j.alcohol.2005.04.005

[19] Deandrea, S., Talamini, R., Foschi, R., Montella, M., Dal Maso, L., Falcini, F., La Vecchia, C., Franceschi, S. and Negri, E. (2008) Alcohol and Breast Cancer Risk Defined by Estrogen and Progesterone Receptor Status: A CaseControl Study. Cancer Epidemiology, Biomarkers and Prevention, 17, 2025-2028. http://dx.doi.org/10.1158/1055-9965.EPI-08-0157

[20] Suzuki, R., Ye, W., Rylander-Rudqvist, T., Saji, S., Colditz, G.A. and Wolk, A. (2005) Alcohol and Postmenopausal Breast Cancer Risk Defined by Oestrogen and Progesterone Receptor Status: A Prospective Cohort Study. Journal of the National Cancer Institute, 97, 1601-1608. http://dx.doi.org/10.1093/jnci/dji341

[21] Huang, W.Y., Newman, B., Millikan, R.C., Schell, M.J., Hulka, B.S. and Moorman, P.G. (2000) Hormone-Related Factors and Risk of Breast Cancer in Relation to Oestrogen Receptor and Progesterone Receptor Status. American Journal of Epidemiology, 151, 703-714. http://dx.doi.org/10.1093/oxfordjournals.aje.a010265

[22] Rosenberg, L.U., Einarsdottir, K., Isaksson Friman, E., Wedrén, S., Dickman, P.W., Hall, P. and Magnusson, C. (2006) Risk Factors for Hormone Receptor Defined Breast Cancer in Postmenopausal Women. Cancer Epidemiology, Biomarkers and Prevention, 15, 2482-2488. http://dx.doi.org/10.1158/1055-9965.EPI-06-0489

[23] Cotterchio, M., Kreiger, N., Theis, B., Sloan, M. and Bahl, S. (2003) Hormonal Risk Factors and Risk of Breast Cancer According to Oestrogen and Progesterone Receptor Subgroup. Cancer Epidemiology, Biomarkers and Prevention, 12, 1053-1060.

[24] Terry, M.B., Zhang, F.F., Kabat, G., Britton, J.A., Teitelbaum, S.L., Neugut, A.I. and Gammon, M.D. (2006) Lifetime Alcohol Intake and Breast Cancer Risk. Annals of Epidemiology, 16, 230-240. http://dx.doi.org/10.1016/j.annepidem.2005.06.048

[25] Zhang, S.M., Lee, I.M., Manson, J.E., Cook, N.R., Willett, W.C. and Buring, J.E. (2007) Alcohol Consumption and Breast Cancer Risk in the Women's Health Study. American Journal of Epidemiology, 165, 667-676. http://dx.doi.org/10.1093/aje/kwk054

[26] Lew, J.Q., Freedman, N.D., Leitzmann, M.F., Brinton, L.A., Hoover, R.N., Hollenbeck, A.R., Schatzkin, A. and Park, Y. (2009) Alcohol and Risk of Breast Cancer by Histologic Type and Hormone Receptor Status in Postmenopausal Women. American Journal of Epidemiology, 170, 308-317. http://dx.doi.org/10.1093/aje/kwp120

[27] Enger, S.M., Ross, R.K., Paganini-Hill, A., Longnecker, M.P. and Bernstein, L. (1999) Alcohol Consumption and Breast Cancer Oestrogen and Progesterone Receptor Status. British Journal of Cancer, 79, 1308-1314. http://dx.doi.org/10.1038/sj.bjc.6690210

[28] Suzuki, R., Orsini, N., Mignone, L., Saji, S. and Wolk, A. (2008) Alcohol Intake and Risk of Breast Cancer Defined by Oestrogen and Progesterone Receptor Status-A Meta-Analysis of Epidemiological Studies. International Journal of Cancer, 122, 1832-1841. http://dx.doi.org/10.1002/ijc.23184

[29] Reding, K.W., Daling, J.R., Doody, D.R., O’Brien, C.A., Porter, P.L. and Malone, K.E. (2008) Effect of Prediagnostic Alcohol Consumption on Survival after Breast Cancer in Young Women. Cancer Epidemiology, Biomarkers and Prevention, 17, 1988-1996. http://dx.doi.org/10.1158/1055-9965.EPI-07-2897

[30] Kwan, M.L., Kuushi, L.H., Weltzien, E., Tam, E.K., Castillo, A., Sweeney, C. and Caan, B.J. (2010) Alcohol Consumption and Breast Cancer Recurrence and Survival among Women with Early-Stage Breast Cancer. The Life after Cancer Epidemiology Study. Journal of Clinical Oncology, 88, 4410-4416. http://dx.doi.org/10.1200/JCO.2010.29.2730

[31] Hillman, R. and Steinberg, S. (1982) The Effects of Alcohol on Folate Metabolism. Annual Review of Medicine, 33, 345-354. http://dx.doi.org/10.1146/annurev.me.33.020182.002021

[32] Choi, S. and Mason, J. (2000) Folate and Carcinogenesis: An Integrated Scheme. Journal of Nutrition, 130, $129-132$.

[33] Oyesanmi, O., Snyder, D., Sullivan, N., Reston, J., Treadwell, J. and Schoelles, K.M. (2010) Alcohol Consumption and Cancer Risk: Understanding Possible Causal Mechanisms for Breast and Colorectal Cancers. Evidence Report/ Technology Assessment No. 197 (prepared by ECRI Institute Evidence-based Practice Center under Contract No. 290-2007-10063-I). AHRQ Publication No. 11-E003. Agency for Healthcare Research and Quality, Rockville, MD.

[34] Slamon, D.J., Clark, G.M., Wong, S.G., Levin, W.J., Ullrich, A. and McGuire, W.L. (1987) Human Breast Cancer: Correlation of Relapse and Survival with Amplification of the HER-2/neu Oncogene. Science, 235, 177-182. http://dx.doi.org/10.1126/science.3798106 
[35] Xu, M., Bower, K.A., Chen, G., Shi, X., Dong, Z., Ke, Z. and Luo, J. (2010) Ethanol Enhances the Interaction of Breast Cancer Cells Over-Expressing ErbB2 with Fibronectin. Alcoholism: Clinical and Experimental Research, 34, 751-760. http://dx.doi.org/10.1111/j.1530-0277.2010.01147.x

[36] Brooks, P.J. and Zakhari, S. (2013) Moderate Alcohol Consumption and Breast Cancer in Women: From Epidemiology to Mechanisms and Interventions. Alcoholism: Clinical and Experimental Research, 37, 23-30. http://dx.doi.org/10.1111/j.1530-0277.2012.01888.x

[37] Ewertz, M., Gillanders, S., Meyer, L. and Zedeler, K. (1991) Survival of Breast Cancer Patients in Relation to Factors which Affect the Risk of Developing Breast Cancer. International Journal of Cancer, 49, 526-530. http://dx.doi.org/10.1002/ijc.2910490409

[38] Rohan, T.E., Hiller, J.E. and McMichael, A.J. (1993) Dietary Factors and Survival from Breast Cancer. Nutrition and Cancer, 20, 167-177. http://dx.doi.org/10.1080/01635589309514283

[39] Zhang, S., Folsom, A.R., Seller, T.A., Kushi, L.H. and Potter, J.D. (1995) Better Breast Cancer Survival for Postmenopausal Women Who Are Less Overweight and Eat Less Fat. The Iowa Women's Health Study. Cancer, 76, 275-283. http://dx.doi.org/10.1002/1097-0142(19950715)76:2<275::AID-CNCR2820760218>3.0.CO;2-6

[40] Saxe, G.A., Rock, C.L., Wicha, M.S. and Schottenfeld, D. (1999) Diet and Risk for Breast Cancer Recurrence and Survival. Breast Cancer Research and Treatment, 53, 241-253. http://dx.doi.org/10.1023/A:1006190820231

[41] Holmes, M.D., Stampfer, M.J., Colditz, G.A., Rosner, B., Hunter, D.J. and Willett, W.C. (1999) Dietary Factors and the Survival of Women with Breast Carcinoma. Cancer, 86, 826-835. http://dx.doi.org/10.1002/(SICI)1097-0142(19990901)86:5<826::AID-CNCR19>3.0.CO;2-0

[42] Goodwin, P.J., Ennis, M., Pritchard, K.I., Koo, J., Trudeau, M.E. and Hood, N. (2003) Diet and Breast Cancer: Evidence that Extremes in Diet Are Associated with Poor Survival. Journal of Clinical Oncology, 21, 2500-2507. http://dx.doi.org/10.1200/JCO.2003.06.121

[43] Barnett, G.C., Shah, M., Redman, K., Easton, D.F., Ponder, B.A.J. and Pharoah, P.D.P. (2008) Risk Factors for the Incidence of Breast Cancer: Do They Affect Survival from the Disease? Journal of Clinical Oncology, 26, 3310-3316. http://dx.doi.org/10.1200/JCO.2006.10.3168

[44] Flatt, S.W., Thomson, C.A., Gold, E.B., Natarajan, L., Rock, C.L., Al-Delaimy, W.K., et al. (2010) Low to Moderate Alcohol Intake Is Not Associated with Increased Mortality after Breast Cancer. Cancer Epidemiology, Biomarkers and Prevention, 19, 681-688. http://dx.doi.org/10.1158/1055-9965.EPI-09-0927

[45] Beasley, J.M., Newcomb, P.A., Trentham-Dietz, A., Hampton, J.M., Bersch, A.J., Passarelli, M.N., Holick, C.N., Titus-Ernstoff, L., Egan, K.M., Holmes, M.D. and Willett, W.C. (2011) Post-Diagnosis Dietary Factors and Survival after Invasive Breast Cancer. Breast Cancer Research and Treatment, 128, 229-236. http://dx.doi.org/10.1007/s10549-010-1323-z

[46] Harris, H.R., Bergkvist, L. and Wolk, A. (2012) Alcohol Intake and Mortality among Women with Invasive Breast Cancer. British Journal of Cancer, 106, 592-595. http://dx.doi.org/10.1038/bjc.2011.561

[47] Newcomb, P.A., Kampman, E., Trentham-Dietz, A., Egan, K.M., Titus, L.J., Baron, J.A., Hampton, J.M., Passarelli, M.N. and Willett, W.C. (2013) Alcohol Consumption before and after Breast Cancer Diagnosis: Associations with Survival from Breast Cancer, Cardiovascular Disease, and Other Causes. Journal of Clinical Oncology, 31, 1939-1946. http://dx.doi.org/10.1200/JCO.2012.46.5765

[48] Thun, M.J., Peto, R., Lopez, A.D., Monaco, J.H., Henley, S.J., Heath Jr., C.W. and Doll, R. (1997) Alcohol Consumption and Mortality among Middle-Aged and Elderly US Adults. New England Journal of Medicine, 337, 1705-1714. http://dx.doi.org/10.1056/NEJM199712113372401

[49] Holm, L.E., Nordevang, E., Hjalmar, M.L., Lidbrink, E., Callmer, E. and Nilsson, B. (1993) Treatment Failure and Dietary Habits in Women with Breast Cancer. Journal of the National Cancer Institute, 85, 32-36. http://dx.doi.org/10.1093/jnci/85.1.32

[50] Vrieling, A., Buck, K., Heinz, J., Obi, N., Benner, A., Flesch-Janys, D. and Chang-Claude, J. (2012) Pre-Diagnostic Alcohol Consumption and Postmenopausal Breast Cancer Survival: A Prospective Patient Cohort Study. Breast Cancer Research and Treatment, 136, 195-207. http://dx.doi.org/10.1007/s10549-012-2230-2

[51] Herbert, J.R., Hurley, T.G. and Ma, Y. (1998) The Effect of Dietary Exposures on Recurrence and Mortality in Early Stage Breast Cancer. Breast Cancer Research and Treatment, 51, 17-28. http://dx.doi.org/10.1023/A:1006056915001

[52] Holm, M., Olsen, A., Christensen, J., Kroman, N.T., Bidstrup, P.E., Johansen, C., Overvad, K. and Tjønneland, A. (2013) Pre-Diagnostic Alcohol Consumption and Breast Cancer Recurrence and Mortality: Results from a Prospective Cohort with a Wide Range of Variation in Alcohol Intake. International Journal of Cancer, 132, 686-694. http://dx.doi.org/10.1002/ijc.27652

[53] Kwan, M.L., Chen, W.Y., Flatt, S.W., Weltzien, E.K., Nechuta, S.J., Poole, E.M., et al. (2013) Postdiagnosis Alcohol Consumption and Breast Cancer Prognosis in the after Breast Cancer Pooling Project. Cancer Epidemiology, Bio- 
markers and Prevention, 22, 32-41. http://dx.doi.org/10.1158/1055-9965.EPI-12-1022

[54] Wu, A.H., Gomez, S.L., Vigen, C., Kwan, M.L., Keegan, T.H., Lu, Y., et al. (2013) The California Breast Cancer Survivorship Consortium (CBCSC): Prognostic Factors Associated with Racial/Ethnic Differences in Breast Cancer Survival. Cancer Causes \& Control, 24, 1821-1836.

[55] National Health Service (NHS) (2010) Alcohol-Use Disorders: Preventing Harmful Drinking. National Institute for Health and Care Excellence (NICE), 27 May 2010. [Updated 2010 Jun] http://guidance.nice.org.uk/PH24/Guidance/pdf/English

[56] Alcohol Units. NHS Choices. Last Updated 26 April 2013. http://www.nhs.uk/Livewell/alcohol/Pages/alcohol-units.aspx 